\title{
ELECTRONIC DICTIONARIES IN EDUCATIONAL PROCESS IN HIGHER EDUCATION
}

\author{
(C) E.G. Vyshkin ${ }^{1}$, N.N. Nemich ${ }^{2}, A . A . K h o k h l o v a^{3}$
}

${ }^{1}$ Utime College, Haifa, Israel;

2 Branch of Military Educational-Research Centre of Air Force Academy after pr. N.E. Zhukovsky and Y.A. Gagarina, Syzran, Russian Federation;

${ }^{3}$ Samara State Technical University, Samara, Russian Federation

- For citation: Vyshkin E.G., Nemich N.N., Khokhlova A.A. Electronic dictionaries in educational process in higher education. Vestnik of Samara State Technical University. Series Psychological and Pedagogic al Sciences. 2021;18(3):115-126. DOI: https://doi.org/10.17673/vsgtu-pps.2021.3.8

The paper considers an application of electronic dictionaries in the educational process as a promising method adapting modern education to the increasing information flow. The possibilities of using electronic dictionaries prove them to be a source of high-quality reference material and useful and necessary modern tool in foreign language learning. The paper points out the functionality of electronic dictionaries, their advantages and disadvantages. The opportunities of electronic dictionaries are wide enough: speed, convenience in finding information, large volume, sound and graphic illustration of the word, spell checker, interactivity, text conciseness, etc. Electronic dictionaries are based on modern lexical material, reflecting the language and speech tendencies, making the translation process fast and interactive, thus becoming a universal tool in the educational process of higher education. The authors point out that students have the opportunity to use the digital resource during lectures, practical studies and independent work.

Keywords: electronic dictionary, mobile apps, web application, educational process, vocabulary, foreign language.

\section{ЭЛЕКТРОННЫЕ СЛОВАРИ В ОБРАЗОВАТЕЛЬНОМ ПРОЦЕССЕ}

\section{(C) Е.Г. Вышкин ${ }^{1}$, Н.Н. Немич ${ }^{2}$, А.А. Хохлова ${ }^{3}$}

${ }^{1}$ Ютайм колледж, Хайфа, Израиль;

${ }^{2}$ Филиал ВУНЦ ВВС «ВВА» имени профессора Н.Е. Жуковского и Ю.А. Гагарина», Сызрань-7, Российская Федерация;

${ }^{3}$ Самарский государственный технический университет, Самара, Российская Федерация

- Аля цитирования: Вышкин Е.Г., Немич Н.Н., Хохлова А.А. Э^ектронные словари в образовательном процессе // Вестник Самарского Государственного Технического Университета. Серия «Психолого-педагогические наукиı. 2021. Т. 18. № 3. C. 115-126. DOl: https://doi.org/10.17673/vsgtu-pps.2021.3.8

Использование электронных словарей в образовательном процессе - это перспективный, необратимый и целенаправленный процесс адаптации современного образования к увеличивающемуся потоку информации в учебном процессе. Возможности использования электронных словарей показывают, что они являются не только источником 
качественного справочного материала, но и полезным и незаменимым современным инструментом при обучении иностранному языку. В данной статье рассматривается функциональность электронных словарей, их положительные и отрицательные особенности. Возможности электронного словаря широки: скорость, удобство поиска информации, достаточно большой объем, наглядность, наличие звуковой графической иллюстрации слова, интерактивность, краткость изложения текста и др. Электронные словари создаются на современном лексическом материале, отражают языковые и речевые тенденции иностранного языка, делают процесс перевода быстрым и интерактивным, тем самым становясь универсальным инструментом в образовательном процессе вуза.

Применение электронных словарей в образовательном процессе в настоящее время является важным средством при обучении иностранным языкам. Полезность использования электронного словаря в учебном процессе заключается в том, что студенты имеют возможность и на лекции, и на практических занятиях, и в процессе самостоятельной работы пользоваться одним и тем же электронным ресурсом, что формирует целостный образ изучаемого предмета в образовательном процессе.

Ключевые слова: электронный словарь, онлайн-переводчик, образовательный процесс, лексика, иностранный язык.

\section{Introduction}

With the introduction of information technology (IT) into educational process the use of electronic dictionaries, mobile apps, and web applications is considered to be relevant and gains popularity. One of the primary teaching tasks is to develop the student's ability to comprehend lexical units and apply them in foreign language learning.

It should be noted that currently there are several notions and terms connected with electronic dictionaries. Most of them are synonyms and can be used interchangeably. In modern papers and publications, we came across: electronic dictionary, e-dictionary, digital dictionary. The words application, resource and tool are sometimes used in the meaning of "dictionary". The terminology is clear enough and there are usually no difficulties in interpreting or understanding it. We use the mentioned terminology in our research as well.

The authors of the article made an attempt to compare the application of different types of electronic dictionaries so comparative method and analysis are used to find out benefits and peculiarities of using this type of dictionaries in language learning. The authors also compare teaching Russian and English languages as foreign languages. The Branch of Military Educational-Research Centre of Air Force Academy after pr. N.E. Zhukovsky and Y.A. Gagarin and Samara State Technical University were the places of the experimental study. Russian Language Department of the Branch of Military Educational-Research Centre of Air Force Academy trains future helicopter pilots for military aviation. Due to the Academy profile only offline dictionaries and applications are used in the learning process. Russian language department teaches Russian as a foreign language to foreign military students. Foreign Languages Department of Samara State Technical University trains engineers of different branches of industry and teaches English, German and French as foreign languages.

Currently, there is a large number of various electronic dictionaries, both offline and online applications. Thesaurus is a particular type of dictionaries used in 
the language learning process. Most often the words are listed conceptually not alphabetically and it is a source of high-quality reference material, a useful and necessary modern tool.

While teaching the students of non-linguistic specialties, a foreign language is unthinkable without mastering a certain amount of special vocabulary presented in the educational terminology minimum. The students need the information containing learning material and, therefore, they should have search and information skills, as well as skills and abilities to use translators, dictionaries, encyclopedias, reference books etc. The work with electronic dictionaries and translators is of great help concerning speed, volume, visualization and technical options presented by digital tools. Additional benefits are associated with the increase of speech culture, enrichment of individual vocabulary, introduction of the norms of the studied language etc. The introduction of digital dictionaries, mobile apps and web applications into the educational activities in universities contributes to high level of professional training of future specialists optimizing the learning process for the students of non-humanitarian specialties.

The mentioned above determines the relevance of the study, the purpose of which is to analyze and compare the authors' experience of using different types of dictionaries in teaching Russian and English in the institutions of higher education.

\section{Literature review}

To observe the topic under consideration the research papers on the given problem were studied. We analyzed the various issues of using electronic dictionaries in language teaching and learning. Modern Russian scientific papers and works on this problem confirm its relevance [Stankevich, 2020; Kazakova, 2013; Fesenko, 2015, Balabanov, 2015, Bogdanova, 2019, Sabelnikova, 2018, etc.].

The literature review revealed the aspects of using modern electronic online and offline dictionaries and thesauri in particular. The aspects can be considered as advantages, disadvantages and peculiarities. It should be noted that they can be divided into technical and purely teaching techniques.

The use of electronic dictionaries in the language learning is a promising, irreversible and purposeful process of adapting modern education to the increasing flow of information in the educational process [1, p. 236].

Online and offline electronic dictionaries are replacing printed publications. To master the lexical features of the studied language in the most practical way, it is useful to refer to modern types of dictionaries. An electronic or digital dictionary can be defined as a program or portal equipped with a user-friendly interface and automatic, quick search facilities [2].

The distinction between the types of electronic dictionaries is made, as a rule, depending on the functions they perform. H. Nesi distinguishes the following categories of electronic dictionaries for language learning depending on technical solutions [3]: internet dictionaries; the glossary for on-line courseware.

Considering the functionality of electronic dictionaries and the reasons why they become popular in learning it is worthwhile mentioning that electronic dictionaries, offering many conveniences (including pronunciation functions), have become an integral part of the student learning process and, therefore, deserve particular attention of teachers and researchers [1, p. 234]. 
Electronic dictionaries are the reality of our time, they have become an important tool for enhancing the learning opportunities for students, which are increasingly preferred and available [4, p. 305].

Work with a dictionary is of great educational value for the formation of the student's linguistic personality, worldview and speech culture. The ability to use an electronic dictionary can solve many problems of linguistic and speech nature. Teachers should guide students how to work with a dictionary, how to find the information and analyze dictionary entries [5, p. 101].

It is important to remember that carefully planned and well-organized work with dictionaries helps to enrich student vocabulary, develops orthographic literacy and speech. It also promotes language culture, respect and love for the native language.

There are several types of tasks when working with a dictionary: tasks for orientation, search for dictionary entries, analysis of the dictionary entry, application of the acquired information to solve the language problem, information application to solve speech problems [ibid, p. 103].

Dictionary work develops the skills to comprehend and remember the correct words spelling. The work should be carried out not only in practical classes, but also in individual work. [6, c. 285].

We strongly agree with N.V. Kopylova, noting that dictionaries are in demand when working with vocabulary, when performing reading or writing tasks. They are of great use for listening and speaking activities [7, p. 61]. It is recommended to distinguish the use of dictionaries during individual and classroom work, where the word usage in context, phraseology, special terms, derivatives, synonymic series and other parameters are of great importance [Ibid, p. 61].

The authors of the article can't but agree with E. K. Gitman stating that information technologies have a significant didactic potential in shaping students' foreign-language communicative competence, allowing students to be involved into foreign-language professional activities, develop language skills and speech abilities, use electronic reference materials and dictionaries [8, p.3-4]. As a visualization, these technologies, due to their multimedia characteristics, allow influencing various types of memory (visual, auditory); organize training exercises of linguistic and speech character; provide reference material, contain dictionary and glossary [ibid, p. 60].

We stick to the point that paper dictionaries sometimes have a limited number of examples. Electronic dictionaries, mobile apps and online applications can provide both word definitions and word examples in context. This helps students to memorize vocabulary more thoroughly, relying on the context. A significant advantage of electronic dictionaries is the use of audiovisual learning tools, i.e. illustrations, videos, audio clips [1, p. 234].

Another important function is connected with the fact that electronic dictionaries can "talk". That is, all the words or the most common vocabulary can be sounded by "live" or synthesized sound [ibid, p. 235].

Electronic dictionaries combine a large volume with user-friendly machine search mechanism. To find a word in an electronic dictionary is to type it in the command line of the dictionary or find it in the alphabetic-root rubricator.

Analyzing the effectiveness of electronic dictionaries in teaching foreign languages we can identify positive and negative aspects of the introduction of digital learning tools into the educational process [9]. 
Learning with the help of electronic dictionaries has a number of advantages: flexibility in working with the translation of the necessary lexical units, the ability to work on pronunciation (voice reproduction) free access. It is worth while noting showing all stable word combinations that include a given word, examples of use, grammatical commentary, transcription, compiling one's own two-sided dictionaries, translation search by all set dictionaries as well as by individual dictionary, fast translations retrieval, correction of a mistyped word or phrase, and fast transition to MS Word, where all word combinations with the word on which the cursor is set are recognized [4, pp. 305-306].

The advantages of electronic dictionaries are strongly associated with time saving, accessibility and mobility, durability, availability of audio versions of lexical units, a format more familiar to young people. The author focuses our attention on such advantages of electronic dictionaries as "multilingualism", "reversibility", "dynamism", as well as convenient structuring and hyperlinks system [10, p. 170].

Examining the positive and negative aspects of using electronic dictionaries, we can formulate the advantages of their search system, which makes it possible to "1) present various language units in the structural-semantic aspects: cognitive, dynamic, functional; 2) show language units as conceptosphere components; This is concerned with thesaurus dictionaries in particular for, as it has already been mentioned above, the words are usually listed conceptually; 3) demonstrate speech potential, manifested in the functioning of various language units [11, p. 48].

Electronic dictionary is an important tool in solving linguistic problems due to the search system simplifying the queries construction. The use of hypertext technology provides choice and the non-linear structure of electronic dictionaries is a certain advantage. Unlike the printed version, the computer version of the dictionary offers a wider range of possibilities. When working with a foreign language it is often necessary to find a word with a few letters known. Therefore, it will be useful to have at one's disposal such a tool as an electronic dictionary with a criteria search function [12, p. 54-55].

The advantages of electronic dictionaries are associated with large volume, speed and convenience of information search, sound graphic illustration; possibility to update and get additional information about the word, possibility to discover comprehensive word meanings, interaction (possibility to discuss the dictionary article and be an author) [13, p. 102-105].

Electronic format provides the opportunity to place additional illustrations, diagrams, pictures in the dictionary article, use a video or recording of live speech, etc. $[14$, c. 48$]$.

N.V. Kopylova highlights updating the corpus of the dictionary, automatic search, as well as additional opportunities for foreign language learners The main features of an electronic dictionary are the volume of the dictionary, translation details, reliability and data relevance [7, p. 61].

L.N. Belyaeva points out significant acceleration of the process for word or word combinations searching, as well as translated meanings in the expanded dictionary article, various possibilities of viewing the content of the dictionary article, the maximum localization of the required information, quick substitution of translated equivalents in text files (by copying them to the clipboard), relative guarantee of keeping the dictionary up-to-date thanks to its frequent updates, the possibility of making additions to the dictionary [15, p.73]. 
However, it is necessary to identify a number of disadvantages when using electronic dictionaries, mobile apps, and web translators. An electronic translator shifts the translation process from the mental to the mechanical activity and does not make you think. The use of electronic dictionaries and translators at exams and tests is still disputable. In most cases students don't use their own knowledge and demonstrate more or less successful translation made by machine. The possibility of obtaining a ready translation of the text with the help of an electronic dictionary for educational purposes to some extent may be attributed to negative factor. Negative aspect is associated with the elimination of the need to perform a set of mandatory thought operations on the technique of translation. Therefore, the process of translation activity is simply replaced by the finished product.

G.R. Chumarina distinguishes the application of electronic dictionaries taking into account advantages disadvantages by the following criteria: usage, presentation, search capabilities, technical aspects. Among disadvantages there are differences of interfaces, the fragmentary articles, the need to use a computer, eye fatigue [16, pp. 267-268].

Among other disadvantages of using electronic dictionaries there is a problem of incompleteness of the dictionary and maintaining the vocabulary base in a state that corresponds to the requirements of the time. However, these problems can be referred equally to paper dictionaries. The fact does not belittle the listed advantages of electronic dictionaries. Therefore, the development of computer lexicography and, in particular, the development of new electronic lexicographic products of various types is, in our opinion, a promising trend of modern applied linguistics.

\section{Materials and methods}

The Russian Department of the Branch of Military Educational-Research Centre of Air Force Academy and Foreign Languages Department of Samara State Technical University teach Russian and European languages the students of nonlinguistic professions and have common teaching goals. The students are to learn a foreign language:

- to read, write, listen and speak;

- to communicate in the most typical situations of everyday and professional communication;

- to use scientific and reference literature to obtain information and improve professional level.

The departments use practical oriented approaches and communicative methods. Offline thesaurus, digital dictionaries and electronic guides are used to introduce and memorize information, practice and test new vocabulary, prepare presentations and reports, compile own mini dictionary on the given topic.

Teachers not only use electronic dictionaries in learning, but also participate in electronic dictionaries development as well. The dictionary development included compiling and updating. For the last three years the branch of the Air Force Academy named after Professor N. E. Zhukovsky and Y.A. Gagarin in Syzran has been actively working on creating electronic dictionaries and textbooks in hypertext form and implementing them in the educational process. Compared to paper textbooks, electronic publications can contain large amount of information.

At present, the Russian Language Department focuses on developing electronic textbooks and dictionaries for the courses: "Russian Language and Culture of Speech", 
"Russian as a Foreign Language", "Foreign Language" for military students of the following specialties: "Aviation Equipment", "Radio Electronic Equipment", "Aircraft Equipment", "Design and Operation of Aircraft". Lexical basis of the professional language is mainly formed by terminology. It takes a lot of time to master it at Russian language classes with foreign servicemen.

Currently, the teaching staff of the branch created an Electronic Study Thesaurus of Basic Concepts and Terms, which is a dictionary of academic terms for military aviation academy. This tutorial is of encyclopedic nature, it has a communicativefunctional speech orientation and serves as a universal reference guide, providing answers to theoretical and practical issues of using the Russian language in various spheres, environments and communication situations [6, p. 283].

The thesaurus is a conceptual dictionary on various subject areas. The work with such a dictionary allows acquiring knowledge on a qualitatively new basis, and also learning to search for the information purposefully and structure it. Our thesaurus development consisted in writing out the most frequently used terms and defining their interpretation. Thus, at this stage about 2000 words from the course of general and special disciplines were selected. Here are some examples of dictionary entries:

Reconnaissance - the active seeking to determine a foe's intentions by collecting and gathering information about an enemy and capabilities in the given environmental conditions

Flight recorder - an electronic recording device placed in an aircraft for the purpose of facilitating the investigation of aviation accidents and incidents

Teachers of the Russian Language Department have created an electronic educational and reference guide "Russian language and speech culture". When developing it, the printed and electronic publications, which most fully comply with the standard program, are concise and convenient for creating hypertexts, contain a large number of exercises and are available in convenient formats, were selected as the source. More details on the development of this tutorial are presented in an article by N.N. Nemich "Electronic Study Guide for the "Russian Language and Speech Culture at a Military Higher Education Institution" [17].

Foreign Languages Department of Samara State Technical University trains future engineers for different branches of industry. Multimedia classrooms provide opportunities to learn foreign languages using digital resources and online applications. Online resources are used during practical studies and conferences. The students are allowed to use their own mobile apps. Students are taught to correct the machine translation and use free cloud stores for automated translation (Smartcat). The application of digital tools is restricted and regulated during tests and exams.

\section{Research results}

Dictionaries created for electronic format have additional computer programs functions. The electronic thesaurus created by the Russian language Department is based on the textbook "Collection of Texts and Tasks on Scientific Style for Foreign Servicemen. Special Vocabulary on Aviation Equipment” by M.A. Mignenko, O.A. Vasilyeva, and A.I. Vyatkina. The thesaurus contains about 150 terms ant the translations in Spanish, French, Arabic and Khmer. The thesaurus is easy to use. It doesn't contain phonetic and grammatical characteristics of terms. Phonetic and grammar blocks are supposed to be options available on demand. The blocks are in the process 
of development yet. Besides translating aviation terms from Russian into Spanish, French, Arabic, and Khmer, this study guide can be useful during extracurricular activities with military students, since it contains texts and videos on aviation subjects.

The thesaurus development consisted of four stages:

1. Selection of lexical units, making a list of terms.

2. Classification and systematization of lexical units, selection of pictures, diagrams, photos, videos.

3. Development of the dictionary composition: vocabulary articles, glossary.

4. Translation of lexical units into other languages.

The thesaurus is created with the help SunRav program and the dictionary entry is presented by French, Spanish, Arabic, Khmer.

Another important technique of this thesaurus is visualization. This helps to present the content of the term and concept, contributes to better fixation and memorization. Foreign servicemen are offered a scheme, a drawing, or a graph in the vocabulary article for a better understanding of the term. Dictionary materials contribute to the formation and the consolidation of student skills and abilities in reading and translation of specialty literature in Russian. Using the dictionary will greatly facilitate individual homework for language learning.

The application of the offline electronic dictionary has already shown its efficiency constituted in time reduction at the stage of new vocabulary introduction. Information perception is facilitated due to the use of pictures, schemes of aviation notions and terms. The learning process becomes dynamic.

As a part of the study we conducted a survey among the military students of the special faculty of the branch of the Air Force Academy in Syzran about the use of electronic dictionaries in classroom and extracurricular activities. The respondents were offered the following questions and the option to be chosen:

1. How often do you use offline electronic dictionaries? (Often, Seldom, Don't use).

2. What do you prefer: to use a paper dictionary or an electronic one? (Paper, Electronic).

3. What are the advantages of an electronic dictionary? (Clarity, Interactivity, Conciseness of the text, Professional orientation, Economy of time, No advantages).

5. Do you think that electronic dictionary is necessary not only when studying a foreign language, but also in other disciplines? (Yes, No, Don't know).

As a result of the conducted questionnaire study it was found out that $100 \%$ of the respondents use electronic dictionaries quite often in their educational activity.

The respondents consider electronic dictionaries to be necessary for learning a foreign language. $22 \%$ of the military students are conservative enough and prefer to use paper dictionaries. Over $80 \%$ of the respondents from the branch of the Higher Educational Institution of Air Force mentioned the time-saving, clear and concise text as the main advantages of the electronic dictionary.

Samara State Technical University conducted a slightly different questionnaire. The questions were connected with online dictionaries and resources. The respondents were asked to mention online translators as well?

As a result of the conducted questionnaire it was found out that $100 \%$ of Samara State Technical University respondents use electronic dictionaries and translators and note almost the same advantages. Answering the question about the most popular and widely used online translators they mentioned: Google, Yandex, Deeple, Multitran, Promt, Translate, Reverso Context, Babylon, Collins. 


\section{Discussion and conclusions}

According to the results of the study, justified be the analyses of scientific publications and our own experience, the following conclusions can be made. The use of electronic online and offline dictionaries as well as mobile apps in the educational process is currently an important tool in teaching and learning foreign languages. The aspects of using digital dictionaries can be considered as advantages, disadvantages and peculiarities. Advantages, disadvantages and peculiarities are divided into relating to technical and purely teaching techniques. Among technical advantages and peculiarities there are speed and convenience of information search, large volume, information updating, audio and visual option, hypertext and internet resources, multiple functionality etc. As for the benefits for organizing teaching methods and procedures there are dynamism, flexibility, reversibility, adaptability and multiple functionality. The tools are successfully used in individual and group work, for classroom activities, home tasks and extracurricular activities. The dictionaries and translator Students have the opportunity to use the same electronic resource during lectures, practical classes, and independent work [17, p. 155]. As for the benefits for learning process these modern types of dictionaries are used to acquire purely linguistic skills in reading, writing, listening and speaking as well as extra linguistic such as language and speech culture and competence.

The benefits of electronic dictionaries application in the educational activities of a university contributes to the improvement of professional training of future specialists.

Thus, we believe that the potential of electronic dictionaries is great. We note the feasibility of their use in the educational process to solve professionally-oriented problems. Electronic dictionaries are a source of high-quality reference guide, a useful and modern tool for teaching and learning foreign languages. Electronic dictionaries have large volume and possibility of full-text search. Surely, the application of such dictionaries and apps will only be beneficial if they are used properly.

\section{REFERENCES}

1. Sabelnikova A.M., Zimovets N.V. The use of electronic dictionaries in teaching English. Lexicography and Communication - 2018: collection of articles. Materials IV int. scientific. Conf., Belgorod, April 26-27. 2018. Ministry of Education and Science of the Russian Federation, National Research University BelSU; Belgorod, 2018. Pp. 233-236.

2. Sinitsa A.I. The use of electronic dictionaries in the lessons of the Russian language and literature. Electronic journal «RONO». 2014. http://erono.ru/art/?ELEMENT_ID=18805 (accessed March 25, 2021).

3. Nesi $H$. Electronic dictionaries for understanding and mastering the vocabulary of a second language: current state. Euralex: European Association of Lexicography. http://www.euralex. org/elx_proceedings/Euralex2000/099_Hilary\%20NESI_Elec tronic\% 20Dictionaries\% 20in\% 20Second\% 20Language\% 20Vocabulary\% 20Com prehension\% 20and\% 20Acquisition_the\% 20State\% 20of\% 20the\% 20Art.pdf (accessed March 21, 2021).

4. Stankevich N.P. Using electronic online dictionaries in the process of teaching a foreign language. Materials of the International scientific-practical conference "Information technologies in political, socio-economic, legal and technical systems». Minsk: BNTU, 2020. Pp. 305-309.

5. Kazakova O.P. Learning to work with a dictionary as the first stage of teaching independent educational activity. Organization of independent work of students: Materials of reports of the 
II All-Russian scientific and practical Internet conference "Organization of independent work of students» (December 6-9, 2013). Saratov: New Project Publ., 2013. 188 p. Pp. 101-103.

6. Bogdanova N.V., Nemich N.N. Working with dictionaries in the classroom on the Russian language with foreign servicemen. Text: Philological, socio-cultural, regional and methodological aspects. Collection of materials of the VI International scientific conference. Ed. G.N. Taranosova, I.A. Izmestyeva, 2019. Pp. 281-285.

7. Kopylova N.V. Using online dictionaries in teaching English for special purposes. Business education in the knowledge economy. 2018. No. 3. Pp. 60-66.

8. Gitman E.K., Timkin Yu.Yu. Information technologies in the process of teaching a foreign language at a university: monograph. Perm: Perm State Agricultural Academy Publ., 2014. 136 p.

9. Balabanov V.B., Maksimik E.V. Electronic means of teaching foreign languages as a way to increase the efficiency of mastering foreign language material. Humanitarian research. 2015. No. 7. Part 1. http://human.snauka.ru/2015/07/12110 (accessed March 21, 2021).

10. Borisova I.V. Electronic dictionaries and translators in foreign language classes in a nonlinguistic university: PRO \& CONTRA. Vestnik VSU. Ser. Linguistics and Intercultural Communication. 2017. No. 2. Pp. 168-172.

11. Fesenko O.P., Laukhina S.S. Electronic dictionaries as a product of modern lexicography. Omsk Scientific Bulletin. 2015. No. 4 (141). Pp. 46-48.

12. Trutnev A.Yu. The use of electronic dictionaries in the professional activity of a translator. Actual problems of modern science, technology and education. Magnitogorsk, 2015. Vol. 3. Pp. 53-56.

13. Rublyova O.S. Electronic encyclopedias and their features. Additional professional education in the context of modernization: collection of articles. Art. IX Int. scientific-practical internet conf. Yaroslavl: YAGPU im. K.D. Ushinsky Publ., 2010. Pp. 129-137.

14. Kantysheva N.G. Hypermedial structural elements of the representation of special knowledge in computer lexicography. Bulletin of the Chelyabinsk State University. Ser. Philology. Art Criticism. 2012. Vol. 71. No. 32 (286). Pp. 47-50.

15. Belyaeva L.N. The potential of automated lexicography and applied linguistics. Izvestia: Humanitarian and scientific journal of Herzen University. 2010. No. 134. Pp. 70-79.

16. Chumarina G.R. Comparative characteristics of electronic and paper dictionaries in the functional aspect. Bulletin of the Chuvash University. 2009. No. 4. Pp. 265-270.

17. Nemich N.N. Creation of an electronic textbook on the discipline «Russian language and culture of speech» in a military university. Actual problems of the humanities and socio-economic sciences. 2016. Vol. 1. Pp. 153-156.

18. Kuregyan A.L., Pertsevaya E.A. Online English learning: main problems and some ways to solve them. Bulletin of Samara State Technical University. Psychological and pedagogical sciences. 2021. Vol. 18. No. 1. Pp. 47-56.

19. Töpel Antje. Review of research into the use of electronic dictionaries. Using online dictionaries. Müller-Spitzer: Carolin (ed.): Using online dictionaries. Berlin: de Gruyter, 2014. pp. 13-54. https://ids-pub.bsz-bw.de/frontdoor/deliver/index/docId/2173/file/Toepel_Review_of_research_2014.pdf (accessed March 21, 2021).

20. Sim Liew Fong, Abdelrahman Osman Elfaki, Md Gapar Md Johar \& Kevin Loo Teow Aik Investigative Study towards the Development of Mobile Language Translator. International Journal of Digital Content Technology and its Applications (JDCTA). 2012. 6(22). DOI: $10.4156 /$ jdcta.vol6.issue22.2

21. John Paul Loucky. Combining the benefits of electronic and online dictionaries with CALL web sites to produce effective and enjoyable vocabulary and language learning lessons. Computer Assisted Language Learning. 2005. No. 18:5. Pp. 389-416. 


\section{СПИСОК АИТЕРАТУРЫ}

1. Сабельникова, А.М. Использование электронных словарей в обучении английскому языку / А.М. Сабельникова, Н.В. Зимовец // Лексикография и коммуникация - 2018: сб. материалов IV междунар. науч. конф., Белгород, 26-27 апр. 2018 г. / М-во образования и науки РФ, НИУ БелГУ ; отв. ред. А.П.Седых. Белгород, 2018. С. 233-236.

2. Синица А.И. Использование электронных словарей на уроках русского языка и литературы [Электронный ресурс]: Электронный журнал «POHO». 2014. URL: http:// erono.ru/art/?ELEMENT_ID=18805 (дата обращения: 25.03.2021).

3. Неси X. Электронные словари для понимания и усвоения лексики второго языка: современное состояние [Электронный ресурc]: Euralex: Европейская ассоциация лексикографии. URL: http://www.euralex.org/elx_proceedings/Euralex2000/099_Hilary\%20 NESI_Elec tronic\%20Dictionaries\%20in\%20Second\%20Language\%20Vocabulary\%20Com prehension\%20and\%20Acquisition_the\%20State\%20of\%20the\%20Art.pdf. (дата обращения: 21.03.2021).

4. Станкевич Н. П. Использование электронных онлайн-словарей в процессе обучения иностранному языку / Н.П. Станкевич // Материалы Международной научнопрактической конференции «Информационные технологии в политических, социальноэкономических, правовых и технических системах». Минск: БНТУ, 2020. С. 305-309.

5. Казакова О.П. Обучение работе со словарем как первый этап обучения самостоятельной учебной деятельности//Организация самостоятельной работы студентов: Материалы докладов II Всероссийской научно-практической интернет-конференции «Организация самостоятельной работы студентов» (6-9 декабря 2013 года). Саратов: Изд-во «Новый Проект», 2013. 188 с. С. 101-103.

6. Богданова Н.В., Немич Н.Н. Работа со словарями на занятиях по русскому языку с иностранными военнослужащими // Текст: Филологический, сооциокультурный, региональный и методический аспекты. Сборник материалов VI Международной научной конференции. Под ред. Г.Н. Тараносовой, И.А. Изместьевой, 2019. С. 281-285.

7. Копьлова Н.В. Использование онлайн-словарей при обучении английскому языку для специальных целей //Бизнес-образование в экономике знаний. №3. 2018. С. 60-66.

8. Гитман Е.К. Информационные технологии в процессе обучения иностранному языку в вузе: монография / Е.К. Гитман, Ю.Ю. Тимкина; ФГБОУ ВПО Пермская ГСХА. Пермь: Изд-во ФГБОУ ВПО Пермская ГСХА, 2014. 136 с.

9. Балабанов В.Б., Максимик Е.В. Электронные средства обучения иностранным языкам как способ повышения эффективности усвоения иноязычного материала // Гуманитарные научные исследования. 2015. № 7. Ч.1 [Электронный ресурс]. URL: http://human.snauka.ru/2015/07/12110 (дата обращения: 21.03.2021).

10. Борисова И. В. Электронные словари и переводчики на занятиях по иностранному языку в неязыковом вузе: PRO \& CONTRA // Вестник ВГУ. Серия: Лингвистика и межкультурная коммуникация. 2017. № 2. С. 168-172.

11. Фесенко О. П., Лаухина С. С. Электронные словари как продукт современной лексикографии// Омский научный вестник № 4 (141) 2015. С. 46-48.

12. Трутнев А.Ю. Использование электронных словарей в профессиональной деятельности переводчика// Актуальные проблемы современной науки, техники и образования. Магнитогорск. Т.3. 2015. с. 53-56.

13. Рублева О.С. Электронные энциклопедии и их особенности // Дополнительное профессиональное образование в условиях модернизации: сб. ст. IX Междунар. науч.практ. интернет-конф. Ярославль: Изд-во ЯГПУ им. К.Д. Ушинского, 2010. С. 129-137.

14. Кантышева Н.Г. Гипермедиальные структурные элементы представления специальных знаний в компьютерной лексикографии / Н.Г.Кантышева // Вестник Челябинского государственного университета. Сер. Филология. Искусствоведение, 2012. Вып. 71. № 32 (286). C. 47-50. 
15. Беляева Л.Н. Потенциал автоматизированной лексикографии и прикладная лингвистика// Известия: Гуманитарно-научный журнал Герценовского университета. 2010. № 134. c. 70-79.

16. Чумарина Г.Р. Сравнительная характеристика электронных и бумажных словарей в функциональном аспекте / Г. Р. Чумарина // Вестник чувашского университета. 2009. №4. с. 265- 270.

17. Немич Н.Н. Создание электронного учебного пособия по дисциплине «Русский язык и культура речи» в военном вузе// Актуальные проблемы гуманитарных и социальноэкономических наук. 2016. Т.1. с. 153-156.

18. Kuregyan A.L., Pertsevaya E.A. Online English learning: main problems and some ways to solve them. Bulletin of Samara State Technical University. Psychological and pedagogical sciences. 2021. Vol. 18. No. 1. Pp. 47-56.

19. Töpel Antje. Review of research into the use of electronic dictionaries. Using online dictionaries. Müller-Spitzer: Carolin (ed.): Using online dictionaries. Berlin:de Gruyter, 2014. Pp. 13-54. https://ids-pub.bsz-bw.de/frontdoor/deliver/index/docId/2173/file/Toepel_Review_of_research_2014.df (accessed March 21, 2021).

20. Sim Liew Fong, Abdelrahman Osman Elfaki, Md Gapar Md Johar \& Kevin Loo Teow Aik Investigative Study towards the Development of Mobile Language Translator. International Journal of Digital Content Technology and its Applications (JDCTA). 2012. 6(22). DOI: $10.4156 /$ jdcta.vol6.issue22.2

21. John Paul Loucky. Combining the benefits of electronic and online dictionaries with CALL web sites to produce effective and enjoyable vocabulary and language learning lessons. Computer Assisted Language Learning. 2005. No. 18:5. Pp. 389-416.

Информаиия об авторах

Ефим Григорьевич Вышкин, доктор филологических наук, профессор. Ютайм колледж, Хайфа, Израиль. E-mail: euphym@gmail.com

Наталья Николаевна Немич, преподаватель кафедры «Русский язык». Филиал ВУНЦ ВВС «ВВА» имени профессора Н.Е. Жуковского и Ю.А. Гагарина». Сызрань-7, Российская Федерация.

E-mail: nemich.natalya@mail.ru

Анна Алексеевна Хохлова, преподаватель кафедры «Иностранные языки». Самарский государственный технический университет. Самара, Российская Федерация. E-mail: khokhlova.anna@mail.ru

Information about the authors

Euphym G. Vyshkin, Doc. Philol. Sci., Professor. Utime College, Haifa, Israel. E-mail: euphym@gmail.com

Natalia N. Nemich, Lecturer, Russian Language Department. Branch of Military Educational-Research Centre of Air Force Academy, named after pr. N.E. Zhukovsky and Y.A. Gagarina. Samara, Russian Federation. E-mail: nemich.natalya@mail.ru

Anna A. Khokhlova, Lecturer, Foreign Languages Department. Samara State Technical University. Samara, Russian Federation. E-mail: khokhlova.anna@mail.ru 